\title{
Inter/mixed cropping of lentil (Lens culinaris) in late sown wheat (Triticum aestivum L.) for higher productivity and profitability of wheat in vertisols of Central India
}

\author{
K.C. Sharma*, P.S. Parmar, K.S. Solanki, A. K. Singh and S. V. Saiprasad \\ ICAR-Indian Agricultural Research Institute, Regional Station, INDORE (M.P.) INDIA \\ (Email: kc_64sharma@yahoo.com)
}

\begin{abstract}
The field experiment was carried out during Rabi season of 2012-013 and 2013-14 at Indore (M.P) to find out the performance of different wheat and lentil inter and mixed cropping systems on the productivity and profitability of late sown wheat.Treatments tested were wheat sole, lentil sole, wheat (line sowing)+lentil (broadcasted), wheat (broadcasted)+ lentil (line sowing), wheat+ lentil (mixed sowing of $100 \%$ seed rates of both), wheat+ lentil (mixed sowing of $50 \%$ seed rates of both), wheat+ lentil (1:1 row ratio), wheat+ lentil ( $2: 1$ row ratio), wheat+ lentil (2:2 row ratio) and wheat+ lentil (3:1 row ratio). Results indicated that line sowing of wheat at $20 \mathrm{~cm}$ a part rows + broad cast sowing of lentil as @ 30kg seed/ha recorded higher values of no. of fertile tillers $/ \mathrm{m}^{2}$, length of spike (cm), number of spikelet/spike, grain yields (5.81 and 5.93 t/ha), biological yields (14.8 and 14.8 t/ha), wheat grain equivalent yields (5.94 and $5.99 \mathrm{t} / \mathrm{ha}$ ) and land equivalent ratio (1.06 and 1.09) than wheat sole along with a bonus yield of lentil grain to the tune of 50 and $20 \mathrm{~kg} / \mathrm{ha}$ during first and second years, respectively. Similar trend was observed fornet benefits and on mean data basis treatment line sowing of wheat + broad casting of lentil recorded highest values of net returns (Rs.55675=00) and $\mathrm{B}: \mathrm{C}$ ratio (2.65). Hence, for getting higher and economic wheat productivity, broad casting of lentil can be done in line sowing of wheat and can be recommended to farmers practice in Central India.

Key Words : Intercropping, Grain, Biological yield, Land equivalent ratio, Lentil, Mixed cropping, Wheat, Wheat equivalent yield

View Point Article : Sharma, K.C., Parmar, P.S., Solanki, K.S., Singh, A.K. and Saiprasad, S.V. (2018). Inter/mixed cropping of lentil (Lens culinaris) in late sown wheat (Triticum aestivum L.) for higher productivity and profitability of wheat in vertisols of Central India. Internat. J. agric. Sci., 14 (1) : 21-26, DOI:10.15740/HAS/IJAS/14.1/21-26.
\end{abstract}

Article History : Received : 23.06.2017; Revised : 02.11.2017; Accepted : 15.11.2017

\footnotetext{
* Author for correspondence:
} 